\title{
Possibilities of the cross-cluster model of the economy in the formation of the strategy of "smart specialization" exclave region
}

\author{
Marina Shalyapina, and Alexey Serbulov \\ Immanuel Kant Baltic Federal University, Kaliningrad, Russia
}

\begin{abstract}
The article explains the expediency of using the cross-cluster model for sustainable economic development of the exclave region of the Russian Federation. The authors of the article describe the strategy of "smart specialization" of the region and its differences from the principles of cluster development. Marina Shalyapina and Alexey Serbulov reveal the potential opportunities of Kaliningrad region, which are necessary for development and implementation of "smart specialization" strategy. The strategy is developed and implemented taking into account the current special legal regime of the special economic zone. The article substantiates the leading role of biomedical cluster in the formation of the cross-cluster model of economy. The authors point out the possibility to combine the competencies of the participants of economic relations at the intersection of industries and technologies. Unification of competencies of participants is carried out for the development of new industries and strengthening of the multiplicative effect of regional development.
\end{abstract}

\section{Introduction}

Regional cluster organizations play a special role in modern conditions of development of national industrial economies. These organizations use the advantages of geographical proximity for economic growth and increase the competitiveness of the region.

However, as the cluster develops, the traditional configuration of its functioning begins to limit the possibility of using all the accumulated competences and resources in their region.

This peculiarity of cluster development necessitates a transition from the traditional cluster to the model of cross-industrial innovation of economic functioning. The model of cross-industrial innovations of economy functioning gives impetus to development of new industries, within which there is a different connection of scientific, industrial and technological competences. The competences allow opening promising opportunities for the development of clusters of new industries, organizing cross-industry innovation flows.

The relevance of this article reveals the active development of the strategy of "smart specialization" abroad, and recently in Russia as well. This circumstance raises the question about the possibility of using clusters for sustainable development of territories.

The problem of determining the potential contribution of clusters to the development and implementation of the strategy of "smart specialization" aimed at sustainable development of the region is of interest. 


\section{Materials and methods}

The study of the processes of formation of the cross-cluster model of development of the regional economy is based on the study of sectoral statistical reporting data provided by the Ministry of Industry and Trade of the Russian Federation, data from official statistics bodies. A significant amount of information for further analysis is provided by regulatory documents (federal laws, decrees of the Government of the Russian Federation, local regulations).

The methodology of research was also based on the application of general scientific and special methods. In the process of research were used logical-intuitive methods (method of statement and scientific discussion of problems, economic analysis, comparative analogies, SWOT-analysis).

\section{Results and discussion}

The concept of cluster has a long evolution, which, as a result, allowed to form a modern cluster approach. Significant influence on the development of the concept had various scientific schools and directions in science, studying the issues of competitiveness and their impact on economic growth.

A cluster can be defined as "a geographical concentration of companies and related organizations (specialized suppliers, partners in related industries, universities, associations, research centers, etc.), which are covered by one certain sphere of activity and interact with each other on the principles of simultaneous competition and cooperation". [2].

The discussion about clusters takes place within a wide range of ideas about the influence of location and spatial proximity on the increase of productivity and competitiveness of industry.

Thus, a number of scientists (E. Bergman, E. Feather, M. Enright, A.V. Babkin, Y.V. Vertakova, S.N. Yashin, etc.) give more importance to the geographical feature in the cluster definition [3 - 7].

Other authors pay more attention to the social characteristics of economic activity, including the importance of the local innovation environment for innovation and entrepreneurship (Grannovetter, Maillat, Crevoisier) [8].

There are parallels between these approaches and approaches to systems of innovation and the importance of personal contacts for knowledge exchange between firms and institutions (Lundvall) [8].

These ideas formed the basis of Porter's highly influential holistic model, which describes the relationship between geographic concentration and industrial competitiveness $[2,9]$.

According to cluster theory, proximity generates advantages related to trade and nontrade interactions between firms, institutions and individuals. Proximity facilitates personal contact, which is necessary to create social capital. Personal contact reduces transaction costs between firms and facilitates the exchange of tacit knowledge through interaction, observation, and imitation.

The benefits of proximity:

- Based on regional external economies of scale and agglomeration. These include increased productivity as a result of the localization of production systems. This circumstance creates opportunities for greater specialization, division of labor, and inter-firm linkages. Agglomeration provides the basis for a greater supply of local skills and a pool of localized knowledge that is shared across firms.

- Related to social networks. They are based on the importance of interpersonal relationships in building trust in business networks, which. Trust creates social capital that transcends the boundaries between firms and institutions. 
- derived from regional innovation systems and local knowledge exchange. These ideas emphasize the importance of local learning processes, which include access to local tacit knowledge and its value in creating competitive advantage.

Regional experts challenged some of the more simplistic interpretations of the meaning of proximity. They expanded the discussion to include other forms of proximity (cognitive, organizational, social, and institutional).

Despite individual disagreements, most scholars agree that clusters provide a conceptual framework for describing and analyzing important aspects of the modern economy. In certain situations (a high degree of diversification of the regional economy, a number of industries have already accumulated a critical mass), the cluster helps to more fully realize the existing potential. This circumstance allows us to consider the cluster approach to be quite effective [9].

In modern conditions, the traditional approach to regional development is not effective enough. It does not allow to respond quickly to changes in global markets with the help of new cluster projects, aimed at the production of unique innovative products.

Another strategic approach to innovative regional development is "smart specialization", proposed by the European scientists D. Forey, P. David and B. Hall. The strategy of smart specialization was further developed in the works of foreign and Russian scientists [10].

There is a limited number of priority spheres, in research and innovations of which the strategy of "smart specialization" allows to direct investments. This circumstance helps the region to choose its own way of development without copying the experience of other territories. Smart specialization focuses on the strengths and comparative advantages of the region. This strategy skillfully combines the achievements in the areas of the cluster triad (business, science, education) and interacts with the authorities, [11].

The idea of formation of specific cluster networks as tools of "smart" development of regions on the basis of innovations is the basis of modern industrial and regional policy of the European Union.

Despite a certain similarity in the essence of a cluster and the strategy of "smart specialization", it is impossible to consider these concepts as identical (see Table 1).

Table 1. Similarities and differences between the concepts of "cluster" and "smart specialization" strategy.

\begin{tabular}{|c|c|}
\hline Similarities & Differences \\
\hline $\begin{array}{l}\text { - Based on } \\
\text { geographic dimension; } \\
\text { aims to take advantage } \\
\text { of proximity to } \\
\text { promote economic } \\
\text { growth and } \\
\text { competitiveness; } \\
\text { - productivity } \\
\text { and innovation are key } \\
\text { factors in } \\
\text { competitiveness. }\end{array}$ & $\begin{array}{l}\text { Clusters: } \\
\text { - The goal of cluster policy in the region is to improve the effectiveness of existing } \\
\text { clusters; } \\
\text { - cover a wide range of sectors of the regional economy; } \\
\text { - focus on existing industry and scientific areas specific to the region; } \\
\text { - are part of the regional innovation economic system. } \\
\text { Strategy of "smart specialization": } \\
\text { - The goal is to orient the regional economy toward the formation of new areas of } \\
\text { activity. These areas are knowledge-based, the choice of which is based on the } \\
\text { strengths of the regional economy; } \\
\text { - focuses on the number of areas (existing or emerging at the junction of economic } \\
\text { or scientific and technical areas), in which leadership can be achieved; the strategy } \\
\text { directs all available resources to achieve this goal; } \\
\text { - prioritizes sectoral and scientific areas in fast-growing industries; } \\
\text { - stimulates the diffusion of knowledge into new areas with a high degree of impact } \\
\text { on the growth of the regional economy. } \\
\text { - is aimed at reforming the regional innovation economic system. }\end{array}$ \\
\hline
\end{tabular}

Source: compiled by the authors

The data in Table 1 show that, despite a number of differences, clusters can be considered as a basis for developing a strategy of "smart specialization" in the regions. With the help of this strategy, innovative development using the unique features of the territory is provided. 
The effect of smart specialization is the growth of labor productivity and innovative activity in the companies included in the clusters.

Let's consider the potential possibilities of Kaliningrad region, necessary when developing the strategy of "smart specialization". "The special legal regime of the special economic zone" in Kaliningrad region has allowed to consider the region as one of the more attractive in the Russian Federation for business. The analysis of the condition of scientific and technical potential of Kaliningrad region for 2016-2019 is presented in table 2.

Table 2. Indicators of innovation activity in Kaliningrad region.

\begin{tabular}{|c|c|c|c|c|c|c|c|}
\hline \multirow[b]{2}{*}{ Indicators } & \multirow[b]{2}{*}{2016} & \multirow[b]{2}{*}{2017} & \multirow[b]{2}{*}{2018} & \multirow[b]{2}{*}{2019} & \multicolumn{3}{|c|}{ Chain growth rate, $\%$} \\
\hline & & & & & $\begin{array}{l}2017 / \\
2016 \\
\end{array}$ & $\begin{array}{l}2018 / \\
2017\end{array}$ & $\begin{array}{l}2019 / \\
2018\end{array}$ \\
\hline $\begin{array}{l}\text { Gross regional product (in basic } \\
\text { prices) mln rubles }\end{array}$ & $\begin{array}{c}3854 \\
99\end{array}$ & $\begin{array}{c}4172 \\
87\end{array}$ & 460854,9 & 492200 & 108,24 & 110,44 & 106,8 \\
\hline $\begin{array}{l}\text { Number of organizations engaged in } \\
\text { research and development (by the } \\
\text { end of the year), units }\end{array}$ & 23 & 23 & 24 & 24 & 100 & 104,3 & 100,0 \\
\hline $\begin{array}{l}\text { Number of employees engaged in } \\
\text { research and development (by the end } \\
\text { of the year), persons }\end{array}$ & 2057 & 1788 & 1113 & 1120 & 86,92 & 62,24 & $\begin{array}{c}100,6 \\
2\end{array}$ \\
\hline $\begin{array}{l}\text { Volume of innovative goods, works, } \\
\text { services in the structure of shipped } \\
\text { own-produced goods, million rubles }\end{array}$ & $\begin{array}{c}994 \\
7\end{array}$ & $\begin{array}{c}1244 \\
, 4\end{array}$ & 1775,2 & 1195,2 & 125,10 & 142,65 & 67,32 \\
\hline $\begin{array}{l}\text { Expenditures on research and } \\
\text { development, million rubles, } \\
\text { Including: }\end{array}$ & $\begin{array}{c}1375 \\
, 6\end{array}$ & $\begin{array}{c}1124 \\
, 0\end{array}$ & 1277,4 & 1773,5 & 81,71 & 113,64 & $\begin{array}{c}138,8 \\
4\end{array}$ \\
\hline internal costs & $\begin{array}{c}1293 \\
, 5\end{array}$ & $\begin{array}{c}1094 \\
, 0\end{array}$ & 1221,6 & 1561,8 & 84,57 & 111,66 & $\begin{array}{c}127,8 \\
4\end{array}$ \\
\hline external costs & 82,1 & 30,0 & 55,8 & 211,7 & 36,54 & 186,0 & $\begin{array}{c}379,3 \\
9\end{array}$ \\
\hline $\begin{array}{l}\text { Expenses on innovation activities of } \\
\text { organizations, million rubles }\end{array}$ & $\begin{array}{c}3856 \\
, 4\end{array}$ & $\begin{array}{c}1464 \\
, 6\end{array}$ & 703,0 & 5943,6 & 37,97 & 47,99 & $\begin{array}{c}845,4 \\
6\end{array}$ \\
\hline & & & & & & Deviation & \\
\hline $\begin{array}{l}\text { Share of products of high-tech and } \\
\text { science-intensive industries in GRP, } \%\end{array}$ & $\begin{array}{c}102 \\
2\end{array}$ & $\begin{array}{c}102 \\
0\end{array}$ & 103,3 & - & 0 & 1,3 & - \\
\hline $\begin{array}{l}\text { GRP volume index (in comparable } \\
\text { prices, } \% \text { of the previous year) }\end{array}$ & 22,3 & 22,4 & 23,9 & - & 0,1 & 1,5 & - \\
\hline $\begin{array}{l}\text { Share of innovative goods, works and } \\
\text { services in the total volume of shipped } \\
\text { goods, works and services }\end{array}$ & 0,2 & 0,3 & 0,3 & 0,2 & 0,1 & 0 & $-0,1$ \\
\hline $\begin{array}{l}\text { Advanced production technologies } \\
\text { created (developed) and used, units }\end{array}$ & 2 & 1 & 2 & 4 & -1 & 1 & 2 \\
\hline $\begin{array}{l}\text { Number of advanced manufacturing } \\
\text { technologies in use, units }\end{array}$ & 854 & 859 & 908 & 930 & 5 & 49 & 22 \\
\hline $\begin{array}{l}\text { Number of patent applications filed, } \\
\text { units. } \\
\text { including: }\end{array}$ & 88 & 118 & 103 & 110 & 30 & -15 & 7 \\
\hline inventions & 52 & 78 & 61 & 69 & 26 & -17 & 8 \\
\hline Useful models & 27 & 33 & 31 & 24 & 6 & -2 & -7 \\
\hline Industrial designs & 9 & 7 & 11 & 17 & -2 & 4 & 6 \\
\hline $\begin{array}{l}\text { Patents issued, units } \\
\text { Including; }\end{array}$ & 60 & 75 & 97 & 101 & 15 & 22 & 4 \\
\hline inventions & 39 & 46 & 59 & 75 & 7 & 13 & 16 \\
\hline Useful models & 20 & 21 & 34 & 17 & 1 & 13 & -17 \\
\hline Industrial designs & 1 & 8 & 4 & 9 & 7 & -4 & 5 \\
\hline
\end{tabular}

Source: Table developed on the basis of data from the territorial body of the State Statistics of the Kaliningrad region $[12,13]$. 
Analysis of the data in the table shows that there are fluctuating growth rates (the lowest value of 106,8\% - 2019/2018). gross regional product in Kaliningrad region from 2017 to 2019). At the same time, the dynamics of formation of this indicator is positive.

A slight increase in the number of scientific organizations in the region could not stop the sharp decline in the number of personnel engaged in research and development (from 2057 people in 2016 to 1120 people in 2019) even with an increase in the cost of research and development (138.84\% - 2019/2018). This circumstance led to a sharp drop in the volume of innovative goods, works, services in the total volume of shipped goods of own production in $2019(67.32 \%-2019 / 2018)$.

The volume of costs for research and development during the study period increased only by 368 million rubles due to the growth of external and internal costs. Such an increase in costs is characterized by an insufficiently high level of development of scientific and scientific-technical activity.

The low level of development of scientific activity is also confirmed by a modest increase in the share of products of high-tech and science-intensive industries in GRP (about 1.5\% during the study period).

The analysis of the indicator indicating the use of advanced technologies in production activities (from 854 in 2016 to 930 in 2019) allows us to state the increase in activity in the field of creation of competitive products with a high share of added value.

If we consider patent activity as a criterion of research and development performance, we should analyze such indicators of patent activity as the receipt of patent applications and issuance of patents for inventions and utility models. The increase of these indicators for the period from 2016 to 2019 indicates the growth of the quality result of scientific activity in Kaliningrad region.

The analysis of scientific and technological potential and innovation activities in the Kaliningrad region for the period from 2016 to 2019 allows us to draw the following general conclusion: despite certain positive changes, indicating the presence of a sufficiently high level of scientific and technological potential, the efficiency of its use is not high (for several years, the region has maintained a 39th place in the rating of the Russian Federation subjects by the Russian regional innovation index value). This confluence of circumstances indicates stagnation caused by insufficient use of the uniqueness of the region in the elaboration of the development strategy.

According to the specific weight of branches of specialization of national and local importance in the total number of branches of specialization of the subject of the Russian Federation (2018) Kaliningrad region belongs to the category "strongly specialized" [14]:

- 4 industries of national and local significance (meat products; fishing and fish production; shipbuilding and water transport; tobacco products);

- 7 industries of local significance (automotive industry; non-metallic ore mining; furniture; water purification and distribution, waste treatment; insurance; textile production; jewelry production).

In connection with the above-mentioned fact, and the absence of significant economic and scientific-technical interrelations between enterprises of various branches on the territory of the region, it is proposed to use the cross-cluster model of economic development as a preferred scenario of the region's development, "...allowing to combine competences of participants at the interface of branches and technologies in order to develop new industries" [1] and create opportunities for multiplicative strengthening of effective and sustainable regional development.

This model can be used within the strategy of "smart specialization", providing socioeconomic development of regions, which is a preferable option for the economy of the exclave Kaliningrad region, having significant resource, transport and other limitations. 
The essence of the strategy of "smart specialization" is to use the strengths of the region, consisting in its geographical location, availability of unique competences and resources, identification of latent opportunities and creation of the basis for building its competitive advantage in the activities with high added value.

It should be noted that "smart specialization" does not necessarily focus only on hightech areas or on innovations with reliance on $R \& D$, it rather implies the development of a unique specialization of the region.

Unlike the strategy of catch-up development, based on copying the experience of strategic planning of leading regions, under the strategy of "smart specialization" regions choose for themselves a number of priority sectors, in which they can gain a sustainable competitive advantage through the development and implementation of innovations.

Such priority direction of economic development of Kaliningrad region is the production of medicines and medical products. And the presence of well-established medical institutions, biotechnological and pharmacological enterprises, specialized scientific organizations, higher educational institutions and infrastructure facilities will allow to form a biomedical cluster in the region, in which new activities are formed at the junction of various areas in healthcare (pharmaceuticals, production of medical equipment, etc.), combining different competencies of cluster participants.

The analysis of the region's strengths necessary for the formation of a biomedical cluster is presented in Table 3.

Table 3. Strengths of the region contributing to the development of a biomedical cluster of the Kaliningrad region as part of the development of "smart specialization".

\begin{tabular}{|c|c|}
\hline $\begin{array}{l}\text { Strengths of the } \\
\text { region for the } \\
\text { development of } \\
\text { the biomedical } \\
\text { cluster }\end{array}$ & $\begin{array}{l}\text { Advantages of using strengths to develop a biomedical cluster within the } \\
\text { framework of smart specialization }\end{array}$ \\
\hline $\begin{array}{l}\text { Geographical } \\
\text { location of the } \\
\text { region }\end{array}$ & $\begin{array}{l}\text { - Development of domestic core markets; } \\
\text { - Access to new foreign markets; } \\
\text { - International cooperation in the field of healthcare. }\end{array}$ \\
\hline $\begin{array}{l}\text { Special Economic } \\
\text { Zone (SEZ) }\end{array}$ & $\begin{array}{l}\text { Privileges for SEZ residents help to attract additional investments to the } \\
\text { region (according to the National Investment Climate Rating in } 2016 \text { the } \\
\text { Kaliningrad region ranked 71st, in } 2019-30 \text { th, in } 2020-23 \text { rd place). }\end{array}$ \\
\hline High investments & It allows the development of the defining areas of the biomedical cluster. \\
\hline $\begin{array}{l}\text { Availability of } \\
\text { natural healing } \\
\text { resources }\end{array}$ & $\begin{array}{l}\text { On the territory of the region there are explored and successfully developed } \\
\text { deposits of medicinal and natural mineral water (used for table use and spa } \\
\text { treatment), therapeutic mud (used in a heated state in the form of baths and } \\
\text { local applications), which indicates the presence of mineral raw materials of } \\
\text { biomedical cluster. }\end{array}$ \\
\hline Amber production & $\begin{array}{l}\text { The region is practically the only owner not only in Russia, but also in the } \\
\text { world of the largest deposit of amber (more than } 90 \% \text { of world reserves). } \\
\text { Amber has a pronounced healing effect and is used in the production of } \\
\text { medicines for treatment and prevention of diseases of the gastrointestinal } \\
\text { tract, for treatment of traumatic injuries of the musculoskeletal system and } \\
\text { skin, diseases of the cardiovascular system and medicinal cosmetics } \\
\text { (cosmetic amber powder, amber massage oil, hygienic lipstick, etc.) }\end{array}$ \\
\hline Migration & $\begin{array}{l}\text { Positive balance of migration to Kaliningrad region and specialists with } \\
\text { medical education in particular. }\end{array}$ \\
\hline
\end{tabular}


Table 3. Continued.

\begin{tabular}{|c|c|}
\hline $\begin{array}{l}\text { Well-developed } \\
\text { innovation } \\
\text { infrastructure and } \\
\text { strong scientific } \\
\text { and laboratory } \\
\text { facilities }\end{array}$ & $\begin{array}{l}\text { Presence of: } \\
\text { - Industrial park "Ecobaltic", which has built a full technological cycle of } \\
\text { production of medicines; } \\
\text { - Scientific-technological park "Factory" which supervises innovation policy } \\
\text { of I.Kant Baltic Federal University, the activity of which is aimed at } \\
\text { development and implementation of innovation projects in various fields and } \\
\text { on the profile of biomedical cluster in particular "development of X-ray } \\
\text { focusing devices and coatings for such devices, development and creation of } \\
\text { functional bioactive surfaces for medical diagnosis", etc., using the scientific } \\
\text { and personnel potential of the university for this purpose. } \\
\text { - KSTU technopark - on the basis of which by providing its own services } \\
\text { and infrastructure the opportunity is created for the development of } \\
\text { innovative companies in various industries (and in the field of biomedicine } \\
\text { including, for example, the development of medical cosmetics, bionic } \\
\text { prosthetic arm, etc.), the interaction between potential consumers and } \\
\text { manufacturers of high-tech products }\end{array}$ \\
\hline Universities & $\begin{array}{l}\text { High level of human resources development due to the presence of an } \\
\text { independent base of specialized training in the region: } \\
\text { - in the field of medicine - the Baltic Federal University named after I.Kant; } \\
\text { the Russian Federal University named after I.Kant; the Russian State } \\
\text { University of Oil and Gas named after Kant. In the field of medicine - the I. } \\
\text { Kant Baltic Federal University; } \\
\text { - In the field of food biotechnology - Kaliningrad State Technical University. }\end{array}$ \\
\hline $\begin{array}{l}\text { Developing } \\
\text { production of } \\
\text { medicines, } \\
\text { technical means } \\
\text { and materials } \\
\text { used for medical } \\
\text { purposes. }\end{array}$ & $\begin{array}{l}\text { - OOO "Infamed K" and OOO "Baltpharmaceutics" implement projects in } \\
\text { the field of pharmaceuticals on the site of the industrial park "Ecobaltic". } \\
\text { - "Factory "Observer" is engaged in the production of unique products for } \\
\text { wheelchair users, designed both for the Russian and foreign markets (the } \\
\text { design capacity of } 2.5 \text { thousand units). And the share of domestic } \\
\text { components with reaching the design capacity is planned to be } 95 \% \text {. It } \\
\text { should be noted that one third of the enterprise's staff consists of people with } \\
\text { disabilities. }\end{array}$ \\
\hline $\begin{array}{l}\text { A number of large } \\
\text { medical } \\
\text { organizations }\end{array}$ & $\begin{array}{l}\text { - federal center of high medical technologies providing a wide range of } \\
\text { medical services (consultations, diagnostics, treatment, including surgical } \\
\text { intervention using the latest technologies and modern medical equipment) } \\
\text { - clinical-diagnostic center of Immanuel Kant Federal University equipped } \\
\text { with the most up-to-date professional equipment; } \\
\text { - Oncologic center in Rodniki under construction, focused on providing } \\
\text { high-tech assistance to patients; } \\
\text { - Dr. Pershin Center for Plastic Surgery; } \\
\text { - Clinic of plastic surgery and cosmetology VIP Clinic; } \\
\text { - a network of sanatoriums ("Amber Coast", "Yantar", "Otradnoye", etc.) } \\
\text { located on the shore of the Baltic Sea. }\end{array}$ \\
\hline
\end{tabular}

Source: complied by authors

The above-mentioned opportunities allow us to formulate the main objectives of the biomedical cluster in the Kaliningrad region:

- implementation of new projects in the field of pharmacology, production of medical devices and technical means of rehabilitation for the disabled;

- increasing the share of added value in the price of manufactured products;

- effective use of the capabilities of specialized industrial parks (private industrial park "Ecobaltic", etc.); 
Benefits from the creation of a biomedical cluster in the territory of the Kaliningrad region:

- The possibility of forming an integrated system of medical care is positively influenced by such factors as: Geographical concentration, specialization in certain types of medical services and the possibility of using a missing service through interaction with other cluster participants, centralization of support activities, including procurement, supplies, use of laundry facilities, etc,

- Organization of access to modern equipment and latest technologies for all participants, including small and medium-sized enterprises that do not have such capabilities;

- possibility of attraction of additional investments for research and development of innovative products;

- possibility of realization of joint projects, the participants of which are universities, scientific organizations and manufacturing enterprises;

- availability in the cluster of clinics, educational and scientific institutions possessing modern equipment provides an opportunity to organize an effective system of training and retraining [15].

At present, in the territory of the Kaliningrad Oblast clusters in the sphere of tourism, production of medicines and medical products, amber and shipbuilding industries are functioning and are being formed in accordance with the strategy of socio-economic development. In 2020, the "International cluster of information technologies North-West" was registered, the main activity of which is "development of computer software".

For effective activity of clusters in Kaliningrad region, in order to intensify the socioeconomic development of the territory and its sustainable functioning, it is necessary to regulate the inter-cluster interaction taking into account the interests of all participants.

At present, the "Center of Entrepreneurship Support of the Kaliningrad region", which implements the state policy aimed at the development of small business, and the "Center of Cluster Development", which assists in the development of interaction between state authorities, educational and scientific institutions, business and investors in implementing joint projects, contribute to achieving this goal. An inter-cluster project, uniting the capabilities of tourist, amber, biomedical, shipbuilding and IT clusters functioning in the territory of the Kaliningrad Oblast, while preserving the possibility of their sectoral specialization, can become a consolidating one

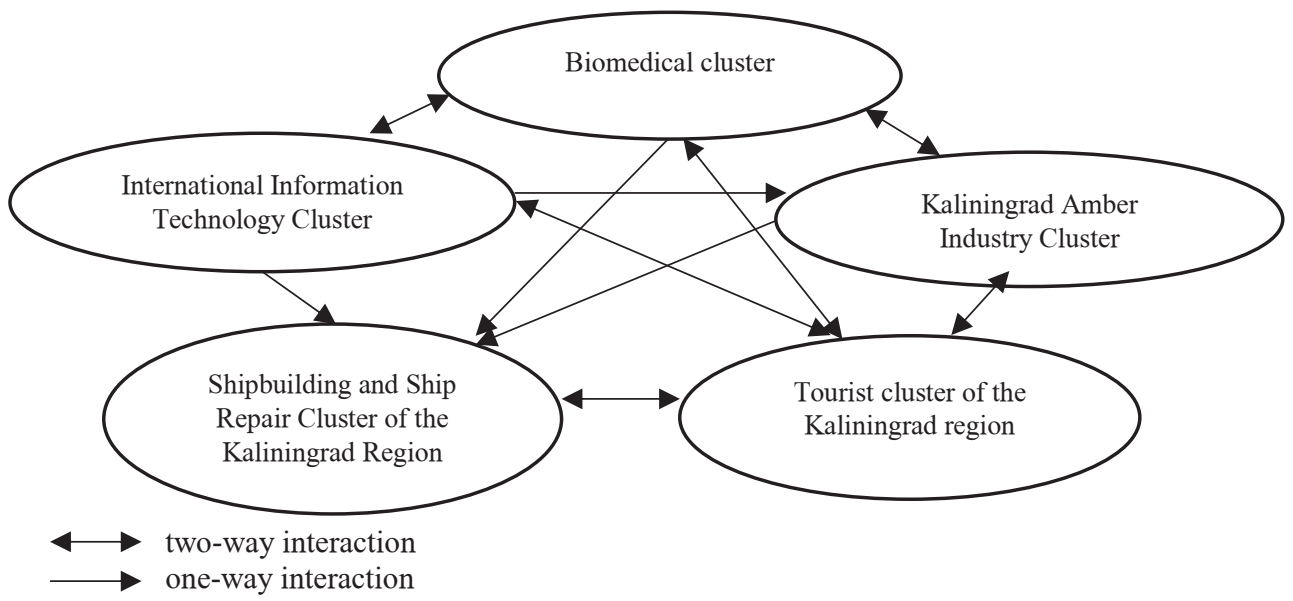

Fig. 1. Inter-cluster interaction of various industry clusters within the same region.

Possible variants of inter-cluster interaction of biomedical cluster with other multiindustry clusters of Kaliningrad region are presented in Table 4. 
Table 4. Interaction of the biomedical cluster with other multi-sectoral clusters of Kaliningrad region

\begin{tabular}{|c|c|c|}
\hline Cluster member & Interacting cluster & The effect of interaction \\
\hline \multirow{3}{*}{ Biomedical cluster } & $\begin{array}{l}\text { Tourism cluster of the } \\
\text { Kaliningrad region }\end{array}$ & $\begin{array}{l}\text { Inter-cluster interaction will allow, on the basis of } \\
\text { cooperation between medical institutions and tourist } \\
\text { organizations, to create a unified chain of integrated } \\
\text { services, which will allow to combine treatment and } \\
\text { recreation. }\end{array}$ \\
\hline & $\begin{array}{l}\text { Amber industry cluster } \\
\text { of the Kaliningrad } \\
\text { region }\end{array}$ & $\begin{array}{l}\text { The use of scientific research in the development of } \\
\text { medicines and cosmetics, dietary supplements based on } \\
\text { amber. }\end{array}$ \\
\hline & $\begin{array}{l}\text { Shipbuilding and ship } \\
\text { repair cluster of the } \\
\text { Kaliningrad region }\end{array}$ & $\begin{array}{l}\text { Production of modern high-tech medical equipment for } \\
\text { hospital ships. } \\
\text { Supply of raw materials for production of amber-based } \\
\text { paintwork materials used in shipbuilding. }\end{array}$ \\
\hline \multirow[b]{2}{*}{$\begin{array}{l}\text { Kaliningrad Amber } \\
\text { Industry Cluster }\end{array}$} & $\begin{array}{l}\text { Shipbuilding and ship } \\
\text { repair cluster of the } \\
\text { Kaliningrad region }\end{array}$ & $\begin{array}{l}\text { Supply of raw materials for production of amber-based } \\
\text { paintwork materials used in shipbuilding. }\end{array}$ \\
\hline & $\begin{array}{l}\text { Tourism cluster of the } \\
\text { Kaliningrad Oblast }\end{array}$ & $\begin{array}{l}\text { Providing excursions for tourists. The object of } \\
\text { demonstration is JSC "Kaliningrad Amber Factory", } \\
\text { including the exhibition hall "Amber Chamber". This allows } \\
\text { not only to actively promote the combine's products, but } \\
\text { also has a positive impact on the development of the } \\
\text { region's tourist potential. }\end{array}$ \\
\hline \multirow{2}{*}{$\begin{array}{l}\text { Cluster of } \\
\text { shipbuilding and } \\
\text { ship repair in the } \\
\text { Kaliningrad region }\end{array}$} & $\begin{array}{l}\text { Tourism cluster of the } \\
\text { Kaliningrad region }\end{array}$ & $\begin{array}{l}\text { Development by the shipbuilding cluster of a promising } \\
\text { segment in the market of high-tech medium-class vessels - } \\
\text { passenger ferries powered by gas-engine ecological fuel. }\end{array}$ \\
\hline & Biomedical cluster & $\begin{array}{l}\text { Development by the shipbuilding cluster of a promising } \\
\text { segment on the market of high-tech medium-class vessels - } \\
\text { hospital ships. }\end{array}$ \\
\hline \multirow{4}{*}{$\begin{array}{l}\text { International cluster } \\
\text { of information } \\
\text { technologies North- } \\
\text { West }\end{array}$} & $\begin{array}{l}\text { Tourism cluster of the } \\
\text { Kaliningrad region }\end{array}$ & $\begin{array}{l}\text { Development of software for creating three-dimensional } \\
\text { reconstruction of cultural heritage objects using modern } \\
\text { information technologies. }\end{array}$ \\
\hline & Amber industry cluster & $\begin{array}{l}\text { Development and implementation of modern technologies } \\
\text { in mining and processing industries. }\end{array}$ \\
\hline & $\begin{array}{l}\text { Shipbuilding and ship } \\
\text { repair cluster of the } \\
\text { Kaliningrad region }\end{array}$ & $\begin{array}{l}\text { Creation of ship-building technologies, such as modern } \\
\text { ship-design systems (6D-design), modular assembly } \\
\text { technologies, robotics, automation of production processes, } \\
\text { implementation of technologies that will improve the } \\
\text { environmental performance of ships, etc. }\end{array}$ \\
\hline & Biomedical cluster & $\begin{array}{l}\text { Software development in the field of diagnostics, treatment, } \\
\text { organization of procurement activities, and data } \\
\text { management. This software will improve the quality of } \\
\text { medical services and reduce the administrative burden on } \\
\text { the staff of clinics and hospitals. } \\
\text { Creation of tourist and educational itineraries for online } \\
\text { applications developed in the North-West International } \\
\text { Information Technology Cluster }\end{array}$ \\
\hline $\begin{array}{l}\text { Tourism cluster of } \\
\text { the Kaliningrad } \\
\text { region }\end{array}$ & $\begin{array}{l}\text { International IT } \\
\text { Cluster } \\
\text { North-West }\end{array}$ & $\begin{array}{l}\text { Creation of tourist and educational itineraries for online } \\
\text { applications developed in the North-West International } \\
\text { Information Technology Cluster. }\end{array}$ \\
\hline
\end{tabular}

Source: complied by authors

\section{Conclusions}

The spatial model of economic functioning is presented as inter-cluster interaction of diversified clusters within one region. This model is aimed at strengthening of integration on the basis of sectoral and regional priorities of socio-economic development. The priorities are based on the interests of all participants. All the above circumstances correspond to the principles of smart specialization. 
Natural, climatic, scientific and industrial potential of the Kaliningrad region suggest that it is possible to form a tourist and recreation cluster and a cluster of medical instrumentation. These cluster formations will fit into the proposed cross-cluster interaction. On the basis of these formations, it is also possible to create a social cluster to support the people with disabilities, difficult financial situation (disability, age changes, large families, etc.). Analogues of such clusters which use the mechanisms of public private partnership exist in the Arkhangelsk region and are being created in the Levoberezhny District of Moscow, in the Sverdlovsk and Tomsk regions.

Further research will be focused on management of inter-cluster interaction of diversified clusters within the same region. The contribution of each cluster to the strategy of sustainable regional development will be assessed in the context of smart specialisation.

\section{References}

1. E. A. Islankina, Innovations in education. Bulletin of the Lobachevsky University of Nizhny Novgorod, 1(1), 36 (2014)

2. M. Porter, Harvard business review, 6, 77 (1998)

3. E. Feser, E. Bergman, Region. Stud., 34(1), 4 (2000)

4. M. J. Enright, Word Link, 5, 24 (1992)

5. A. V. Babkin, Economic sciences, 1(235), 9 (2016)

6. Yu. V. Vertakova, Technical and technological problems of service, 1(27), 92 (2014)

7. S. N. Yashin, Yu. V. Trifonov, E. V. Koshelev, Financial Analytics: problems and solutions, 24(306), 14 (2016)

8. European Commission, Directorate General for Research and Innovation, The role of clusters in smart specialization strategies, 59 (Luxembourg: Publications Office of the European Union, 2013)

9. C. Ketels, G. Lindgvist, O. Solvell, The Cluster Observatory, 50 (2012)

10. D. Foray, P. David, B. Hall, Smart Specialisation: The Concept. Knowledge Economists Policy Brief., 9 (2009) http://ec.europa.eu

11. E. Kutsenko, E. Islankina, A. Kindras, Forsyth, 12(1), 25 (2018)

12. E. S. Alexandrova et al, Kaliningrad Region in numbers. 2019, 144 (KaliningradstatKaliningrad, 2019)

13. E. S. Alexandrova et al, Kaliningrad Region in numbers. 2020, 146 (KaliningradstatKaliningrad, 2020)

14. V. L. Abashkin, L. M. Gokhberg, Ya. Yu. Eferin et al, Atlas of economic specialization of the regions of Russia Nats. research. Higher School of Economics, 264 (Moscow: Higher School of Economics, 2021)

15. E. A. Islankina, E. S. Kutsenko, F. N. Filina, V. I. Pankevich, et al, Foundation of the International Medical Cluster; Nats. research. Higher School of Economics, 160 (Moscow, Higher School of Economics, 2019) 